\title{
A canção de funk carioca no ensino de Português como Língua Adicional: uma proposta de material didático
}

\author{
José Peixoto Coelho de Souza ${ }^{1}$ \\ Graziela Hoerbe Andrighetti ${ }^{2}$
}

\section{Resumo}

Neste artigo apresentamos e analisamos uma unidade didática sobre o funk carioca para refletir sobre como materiais didáticos com base em canções podem estimular a leitura como prática social (RIO GRANDE DO SUL, 2009). Partimos de uma perspectiva social de uso da linguagem e da conceito de canção como um gênero discursivo oral, sincrético e secundário (CARETTA, 2007, 2011; COELHO DE SOUZA, 2010). Com este trabalho, esperamos contribuir para reflexões sobre o uso da canção em aulas de línguas através de práticas pedagógicas que levem os alunos a tornarem-se leitores ativos e críticos frente ao que leem.

Palavras-chave: Ensino de Línguas Adicionais; Canção como Gênero Discursivo; Funk Carioca.

\begin{abstract}
This paper presents and analyses a lesson plan on funk carioca aiming to reflect on how teaching materials based on songs can be used to foster reading as a social practice (RIO DE GRANDE DO SUL, 2009). This lesson plan is aligned with the perspective of language as a social practice and with the concept of songs as an oral, sincrectic and secondary speech genre (CARETTA, 2007, 2011; COELHO DE SOUZA, 2010). With this paper we hope to contribute to discussions on the use of songs in the language classroom through an example of pedagogical practices which aim to encourage students to become active and critical readers.
\end{abstract}

Key-words: Foreign Language Teaching; Song as a Speech Genre; Funk Carioca.

\section{Introdução}

O uso de materiais didáticos abordando canções é uma prática pedagógica bastante comum no ensino de português como língua adicional (PLA), tanto pela canção brasileira ser uma manifestação artística de grande representatividade na nossa cultura quanto por estar

\footnotetext{
${ }^{1}$ University of Manchester, School of Arts, Languages and Cultures, Manchester, Inglaterra, jose.coelhodesouza@manchester,ac,uk

$\frac{2}{2}$ Escola de Português Bem Brasil, Porto Alegre, Rio Grande do Sul, Brasil, ghandrighetti@gmail.com

Revista Leitura V.1 no 55 - jan/jun 2015 - Número temático: Estudos em perspectivas dialógicas. A canção de funk carioca no ensino de Português como Língua Adicional: uma proposta de material didático. José Peixoto Coelho de Souza e Graziela Hoerbe Andrighetti - p. $41-66$.
} 
presente no dia a dia dos alunos, especialmente dos que aprendem a língua em contexto de imersão. Entretanto, a abordagem dada a textos desse gênero em livros didáticos de PLA geralmente tem como objetivo a leitura e/ou a compreensão oral da letra da canção desvinculada de seus usos sociais e de elementos da música, sua outra linguagem constitutiva, ignorando aspectos relacionados à canção enquanto gênero discursivo, como os possíveis contextos de produção, circulação e recepção e a interlocução por ele delimitada (quem fala, para quem e com que propósito) e a articulação entre letra e música para a construção dos seus sentidos (COELHO DE SOUZA, em preparação). Tampouco são levadas em conta questões culturais presentes na letra (seu tema e termos presentes em diferentes variantes regionais ou socioculturais) e na música (uso de determinados instrumentos musicais e elementos presentes no arranjo), assim como características da linguagem oral (apagamentos, alongamentos, coarticulações e sotaques) presentes nesse gênero do discurso.

Nesse contexto, o presente artigo tem como objetivo apresentar e analisar trechos de uma unidade didática ${ }^{3}$ tendo como gênero estruturante a canção de funk carioca, com o propósito de ilustrar como materiais didáticos com base em canções podem servir como base para práticas pedagógicas que estimulem a leitura ${ }^{4}$ enquanto prática social (GIBBONS, 2002; SCHLATTER, 2009; RIO GRANDE DO SUL, 2009), tendo em vista uma abordagem mais holística de canções em aulas de línguas que possa fomentar o desenvolvimento do(s) letramento(s) dos alunos.

\section{Leitura como prática social}

Desde o lançamento dos Parâmetros Curriculares Nacionais (PCN) (BRASIL, 1998), tem-se proposto que o ensino de línguas (materna e adicionais) tome como base o estudo de textos que atualizam variados gêneros do discurso, partindo dos que circulam nas esferas mais

\footnotetext{
${ }^{3}$ Neste trabalho, entendemos unidade didática como uma sequência de tarefas pedagógicas (BULLA, GARGIULO e SCHLATTER, 2009), sendo cada uma destas entendida como "uma proposta aos alunos quanto ao que vamos fazer, tendo em vista determinados propósitos e interlocutores" (SCHLATTER; GARCEZ, 2012, p. 95).

${ }^{4}$ Utilizamos o termo leitura para referir-nos à canção porque a abordagem sociohistoricamente construída de canções em aulas de (P)LA envolve o estudo da transcrição da letra da canção, ou seja, um gênero escrito.

Revista Leitura V.1 no 55 - jan/jun 2015 - Número temático: Estudos em perspectivas dialógicas. A canção de funk carioca no ensino de Português como Língua Adicional: uma proposta de material didático. José Peixoto Coelho de Souza e Graziela Hoerbe Andrighetti - p. $41-66$. 
privadas às mais públicas, a fim de propiciar aos alunos a reflexão sobre o mundo em que vivem e melhor prepará-los para nele agir através da linguagem (RIO GRANDE DO SUL, 2009; SCHLATTER, 2009; SCHLATTER; GARCEZ, 2012).

Segundo Bakhtin (2003), os gêneros do discurso são tipos de enunciados surgidos nas diferentes esferas da atividade humana, que apresentam uma relativa estabilidade no que diz respeito aos seus três elementos constitutivos (o conteúdo temático, a construção composicional e o estilo), o que acaba por delimitar possíveis temas e modos como os mesmos são mais frequentemente expressos nesses gêneros. Do mesmo modo, conforme Rodrigues (2005, p. 166), os gêneros também projetam uma interlocução, ou seja, para o locutor, "os gêneros constituem-se como 'índices' sociais para a construção do enunciado (quem sou eu, quem é meu interlocutor, como este me vê, o que dizer, como dizer, para que etc.)", enquanto para o interlocutor, "os gêneros funcionam como um horizonte de expectativas (de significação), indicando, por exemplo, a extensão aproximada da totalidade discursiva, sua determinada composição, bem como os aspectos da expressividade do gênero e do enunciado".

Na perspectiva da educação linguística (BRASIL, 1998; SCHLATTER, 2009; RIO GRANDE DO SUL, 2009; SCHLATTER; GARCEZ, 2012) à qual nos afiliamos, o estudo e a produção de textos (orais ou escritos) pertencentes a diferentes gêneros discursivos permitem ampliar as competências de uso da língua dos educandos através de materiais didáticos que promovam a leitura e a escrita enquanto prática social, lidando com questões referentes ao gênero e à situação de interlocução por ele projetada para a construção dos sentidos do texto em estudo. Conforme os Referenciais Curriculares do Rio Grande do Sul (doravante RC),

\footnotetext{
a ampliação das competências de uso da língua que deve ser oportunizada aos alunos inclui e privilegia a diversificação dos sentidos do letramento, de tal forma que eles possam agir no mundo não apenas por meio das conversas cotidianas, entre interlocutores situados em esferas mais próximas de interação, mas também por meio da escrita, lendo e produzindo textos, por meio de interações nas quais lancem mão de competências para ler e para produzir textos orais letrados. (RIO GRANDE DO SUL, 2009, p. 55).
}

Por essa razão, entendemos que é papel do professor de (P)LA promover práticas pedagógicas que estimulem o uso da linguagem em contextos significativos para os alunos, visto que "não Revista Leitura V.1 no 55 - jan/jun 2015 - Número temático: Estudos em perspectivas dialógicas. A canção de funk carioca no ensino de Português como Língua Adicional: uma proposta de material didático. José Peixoto Coelho de Souza e Graziela Hoerbe Andrighetti - p. $41-66$. 
basta apenas saber ler e escrever, é preciso também saber fazer uso do ler e escrever, saber responder às exigências de leitura e de escrita que a sociedade faz continuamente" (SOARES, 1999, p. 20).

Além disso, entendemos que o trabalho com gêneros permite abordar língua e cultura de maneira integrada em sala de aula (ANDRIGHETTI; SCHOFFEN, 2012), propiciando ao aluno o reconhecimento de e/ou a familiarização a determinadas práticas sociais - a partir de discussões acerca de interlocutores, propósitos, comportamentos, atitudes, valores, posições, vozes etc., assim como uma compreensão mais aprofundada dessas práticas sociais - a fim de nelas participar de maneira mais confiante e crítica caso assim desejar. Nesse sentido, concordamos com Schlatter (2009, p. 12) quando afirma que

o objetivo da aula de LE [língua estrangeira] é tornar-se um espaço para reflexão, autonomia e sensibilização ao outro na busca por uma compreensão da sua própria realidade e de uma ampliação de sua participação em práticas sociais onde a língua estrangeira e as práticas de leitura e escrita são produtos culturais e simbólicos valorizados.

No que se refere mais especificamente à leitura enquanto prática social, Luke e Freebody (1990, apud GIBBONS, 2002) discutem os quatro papeis que os bons leitores lançam mão ao se engajarem na leitura de um texto: decodificador, participante, usuário e analista. O primeiro papel, decodificador, refere-se ao domínio da tecnologia da linguagem escrita, como o fato de a leitura (em muitas línguas) dar-se da esquerda para a direita, o reconhecimento do alfabeto e da sua relação com os sons. O segundo, participante, diz respeito à capacidade de o leitor relacionar o seu conhecimento prévio (conhecimento de mundo, conhecimento da cultura e dos gêneros discursivos) com o que conteúdo do texto. $\mathrm{O}$ terceiro papel, usuário, refere-se a possuir os recursos para realizar a leitura de um texto pertencente a um dado gênero discursivo compatível com as práticas sociais às quais ele se insere. O último, analista, relaciona-se ao fato de que um bom leitor é capaz de ler criticamente, reconhecendo as ideologias subjacentes ao texto, sendo elas explícitas ou implícitas, visto que todo texto é escrito por um autor e que, consequentemente, expressa um ponto de vista.

Reconhecendo os papeis envolvidos no ato de ler como prática social, neste trabalho a leitura é entendida como

Revista Leitura V.1 no 55 - jan/jun 2015 - Número temático: Estudos em perspectivas dialógicas. A canção de funk carioca no ensino de Português como Língua Adicional: uma proposta de material didático. José Peixoto Coelho de Souza e Graziela Hoerbe Andrighetti - p. $41-66$. 
(re)agir e posicionar-se criticamente frente a diferentes textos. Ler envolve combinar letras, sons, imagens, gestos, relacionando-os com significados possíveis, lançar mão do conhecimento prévio para participar da construção dos sentidos possíveis do texto, agir conforme a expectativa de leitura criada pelo contexto de comunicação e ser crítico em relação à ideologia implícita, reconhecendo que qualquer texto atualiza um ponto de vista, pois tem um autor (RIO GRANDE DO SUL, 2009, p. 39).

Entretanto, como fica evidente a partir da definição de leitura acima apresentada, diferentes gêneros requerem competências distintas para a sua leitura, uma vez que podem ser formados por outras linguagens além da verbal, como é o caso da canção, gênero estruturante do material didático a ser analisado.

Neste trabalho, entendemos canção como um gênero oral, sincrético e secundário (CARETTA, 2007, 2011; COELHO DE SOUZA, 2010). Em outras palavras, a canção existe apenas em sua materialidade sonora composta pelas linguagens verbal e musical, seus sentidos não decorrem apenas da união das duas linguagens, mas também dos que emergem a partir desse sincretismo, e sua letra reelabora elementos de outros gêneros do discurso, sejam eles primários ou secundários, orais ou escritos. Devido ao seu sincretismo, três competências estão envolvidas na construção dos sentidos de uma canção: a verbal, a musical e a literomusical (COSTA, 2002), sendo esta última a capacidade de construir novos sentidos a partir da articulação entre as duas linguagens ${ }^{5}$.

No que diz respeito à leitura de uma canção como prática social, pensamos que isso também envolve entender a canção em relação à interlocução por ela projetada, ou seja, a compreensão de quem a criou e por quê, e de que os seus sentidos também são construídos na interação entre canção e ouvinte/leitor. A fim de melhor entender essa interlocução, partimos do pressuposto de que o gênero musical ao qual uma canção pertence (tal como o rock, a bossa nova e o funk carioca, por exemplo) determina não apenas seus elementos constitutivos - tema, construção composicional e estilo das linguagens verbal e musical - mas, da mesma forma, delimita seus possíveis ouvintes presumidos e contextos de produção, circulação e recepção (COELHO DE SOUZA, 2010). Nessa perspectiva, no caso da canção de funk

5 Por exemplo, na canção Construção, composta por Chico Buarque, a sensação da monotonia presente na rotina do casal descrito na letra parece ser reiterada pela melodia que repete o mesmo motivo.

Revista Leitura V.1 no 55 - jan/jun 2015 - Número temático: Estudos em perspectivas dialógicas. A canção de funk carioca no ensino de Português como Língua Adicional: uma proposta de material didático. José Peixoto Coelho de Souza e Graziela Hoerbe Andrighetti - p. $41-66$. 
carioca, objeto de estudo da unidade didática aqui tratada, sua leitura envolve situá-la em seu contexto de produção, refletindo sobre sua relação com quem a criou, para quem se direciona e com que propósitos. Implica também em vê-la como algo maior, situado na história da sociedade brasileira (a repercussão que o funk carioca teve e tem), e considerar questões como o empoderamento dado a sua comunidade de origem e as questões das identidades sociais dentro dos membros dessa comunidade.

Após tratarmos da noção de gêneros do discurso, da sua implicação para o ensino de leitura como prática social e das especificidades do estudo da canção como gênero discursivo, na seção seguinte analisamos trechos de uma unidade didática que aborda o gênero canção de funk carioca com o objetivo de refletir sobre os aspectos que consideramos necessários em uma unidade didática que se proponha a trabalhar com canções levando em conta os diferentes papeis esperados para a realização da sua leitura e as competências necessárias para sua compreensão.

\section{O material didático}

A unidade didática a ser aqui apresentada foi por nós reelaborada a partir da unidade ${ }^{6}$ de funk carioca criada originalmente para o curso de Canção Brasileira do Programa de Português para Estrangeiros da Universidade Federal do Rio Grande do Sul. O material didático das nove unidades que compõem o curso parte da canção como gênero estruturante, buscando estimular o estudo dos seus sentidos a partir não apenas da letra, mas da música e das suas possíveis articulações com a letra. Entre seus objetivos, o curso almeja apresentar aos alunos um recorte da música popular brasileira composto por oito gêneros musicais, promover a reflexão sobre temas presentes nas letras das canções estudadas e o reconhecimento de elementos musicais mais característicos de cada um dos gêneros estudados (COELHO DE SOUZA, 2009).

Devido à sua presença em diferentes meios de comunicação, ao seu consumo por diferentes grupos socioeconômicos e às opiniões acirradas que este gênero musical costuma atrair (MEDEIROS, 2006; VIANA, 2010), decidimos reestruturar a unidade de funk carioca

6 A unidade original foi elaborada por Ana Cristina Balestro, André Fuzer, Arildo Aguiar, Bruno Rodrigues e José Coelho de Souza.

Revista Leitura V.1 no 55 - jan/jun 2015 - Número temático: Estudos em perspectivas dialógicas. A canção de funk carioca no ensino de Português como Língua Adicional: uma proposta de material didático. José Peixoto Coelho de Souza e Graziela Hoerbe Andrighetti - p. $41-66$. 
por almejar que, ao se deparar com canções como Rap da Felicidade e Diretoria - objetos de estudo da unidade - os alunos tenham a oportunidade de entendê-las em seu contexto de produção, para poder querer se tornar um apreciador e/ou dizer que se identifica com esse gênero musical, ou simplesmente poder dizer que não gosta e que não se afilia a ele.

Dos possíveis assuntos relacionados ao gênero que poderiam ser abordados, como a questão da sensualidade/sexualidade explícita presente nas letras e nas danças, as representações da mulher pelos e pelas $\mathrm{MCs}^{7}$, e o funk e a violência nos morros, decidimos abordar o tema do funk carioca como voz das comunidades que vivem nos morros do Rio de Janeiro, procurando enfatizar suas temáticas (e os aspectos sociais nela retratados), seu contexto de produção (que comunidades são essas), e seu papel social (quem está ganhando voz a partir da sua disseminação). Desse modo, esperamos fornecer aos nossos alunos elementos para uma compreensão mais ampla do funk carioca, o que envolve refletir sobre o teor do que está sendo explicitado nas letras, de que modo está sendo explicitado e sobre quem está por traz dessa voz, e dos elementos musicais do gênero, como os instrumentos, o andamento e o vocal, a fim de que possam reagir criticamente a ele (SCHLATTER, 2009; RIO GRANDE DO SUL, 2009).

Pensar em praticas pedagógicas que funcionem como uma ponte para esse entendimento, ou seja, propor tarefas de ensino que possibilitem aos alunos também assumirem não apenas o papel de decodificadores, mas também de participantes, usuários e analistas dos textos com os quais irão interagir (LUKE; FREEBODY, 1990, apud GIBBONS, 2002), torna-se fundamental em aulas de (P)LA. Para isso, é preciso que o professor comprometido com a educação linguística reflita sobre os objetivos de suas práticas pedagógicas e auxilie os alunos a assumirem esses papéis para que possam compreender o texto, ponderar sobre e posicionar-se frente a ele.

$\mathrm{Na}$ unidade analisada neste artigo, selecionamos duas canções para serem estudadas a fundo, Rap da Felicidade, de MC Cidinho e Doca, e Diretoria, de MC Sapão, propondo tarefas que analisam a letra, a música e suas articulações entre si para a construção dos sentidos das canções. A unidade didática está organizada da seguinte forma: I - Pra Começar,

$7 \quad$ Termo geralmente utilizado para referir-se ao cantor e/ou compositor de funk carioca, que significa Mestre de Cerimônias.

Revista Leitura V.1 no 55 - jan/jun 2015 - Número temático: Estudos em perspectivas dialógicas. A canção de funk carioca no ensino de Português como Língua Adicional: uma proposta de material didático. José Peixoto Coelho de Souza e Graziela Hoerbe Andrighetti - p. $41-66$. 
II - Conhecendo a Canção (Rap da Felicidade), III - Conhecendo a Canção (Diretoria), IV Refletindo sobre as Canções (o funk e os MCs), V - Ouvindo Música, VI - O que Pensam sobre Isso?, VII - Produção Escrita e VIII - Conhecendo Mais. A seguir, apresentamos e analisamos trechos de cada uma das etapas, buscando refletir de que forma propiciam aos alunos uma tomada de decisão frente aos textos.

\section{Pra Começar}

O objetivo desta etapa introdutória é ativar o conhecimento prévio dos alunos sobre o gênero estruturante do material a partir da leitura de comentários sobre o funk carioca extraídos de um site da internet ${ }^{8}$, nos quais são convidados a reconhecer as opiniões neles expressas e posicionarem-se em relação a elas, para depois conversar sobre questões referentes à cidade onde esse estilo musical surgiu e ao próprio gênero. Nossa opção em iniciar a unidade com esses textos deu-se por esperarmos que ao se deparar com opiniões reais a respeito de um gênero musical em circulação na sociedade brasileira, os alunos se sentirão instigados a tomar uma ação no sentido de procurar compreender o que está por trás de tais apreciações, aprofundando-se nas razões defendidas ou refutadas, e a explicar o seu posicionamento sobre o assunto.

\section{Conhecendo a canção (Rap da Felicidade)}

As questões 1 a 12 sobre o Rap da Felicidade levam os alunos a perceber diferentes aspectos da canção, como os discursivos (quem são os sujeitos presentes na letra, de onde falam, o que falam e para quem falam) e os relacionados à música (instrumentos, andamento, sensações etc.), e a refletir sobre aspectos culturais nela retratados.

A partir da questão 1, os alunos têm um primeiro contato com a canção, ao ouvir o refrão e sua repetição, com o intuito de chamar a atenção para o reconhecimento de elementos musicais (número de instrumentos que compõem o arranjo, andamento, características da performance vocal) e também observando quais reações ela gera no ouvinte (como ele sente a

\footnotetext{
${ }^{8}$ http://br.answers.yahoo.com/question/index?qid=20130418170039AAY0Q8g

Revista Leitura V.1 no 55 - jan/jun 2015 - Número temático: Estudos em perspectivas dialógicas. A canção de funk carioca no ensino de Português como Língua Adicional: uma proposta de material didático. José Peixoto Coelho de Souza e Graziela Hoerbe Andrighetti - p. $41-66$.
} 
batida e a melodia) e em que situações os alunos ouviriam a canção. Na segunda pergunta, propomos uma discussão sobre alguns aspectos específicos do gênero canção, como o papel do refrão e sua relação com a construção composicional. No caso da canção de funk carioca, o refrão costuma ser apresentado antes da primeira estrofe como forma de familiarizar o ouvinte, estratégia que tem por objetivo "facilitar a memorização, bem como incentivar o acompanhamento e a participação do ouvinte no ato de audição" (OLIVEIRA, 2009, p. 49). Além disso, o objetivo das questões c e d é estimular a prática da competência literomusical (COSTA, 2002) a partir do reconhecimento da sensação de eco que a repetição de palavra feliz em uma mesma melodia pode provocar no ouvinte e de como o verso "Fé em Deus, DJ" parece ser utilizado para introduzir a batida da música.

O foco das questões 3 e 4 está na preparação para o trabalho com a letra da canção e numa familiarização ao tema nela retratado. Para isso, fizemos uma seleção de palavras presentes na letra relacionadas ao tema abordado pela canção com o objetivo de fornecer mais subsídios aos alunos para um panorama geral do que trata a letra (questões sociais, diversão, sofrimentos e angustias dos moradores dos morros cariocas), assuntos comumente retratados em canções desse gênero musical, criando expectativas com relação ao seu conteúdo, para que possam debruçar-se sobre o seu estudo e compreender melhor os meandros do que está sendo exposto nela.

A proposta das perguntas 6,7 e 8 é criar oportunidades para que os alunos se aproximem do cotidiano retratado pelos compositores e compreendam a realidade por eles descrita, explorando as relações de pertencimento e poder expressas na canção, dando insumos para uma leitura mais crítica da(s) ideologia(s) a ela subjacentes.

Nas perguntas que seguem $(9,10,11$ e 12), há uma proposta para que os alunos retomem a canção como um todo, após terem analisado-a de forma mais minuciosa em cada estrofe, a fim de entender quais são os objetivos associados ao gênero canção de funk carioca, a quem ele dá voz e/ou quem dá voz a muitas de suas canções, que relações sociais podem ser traçadas, para então refletir sobre a combinação entre letra e música, articulando as duas linguagens constitutivas do gênero.

Ainda no que diz respeito à canção em estudo, é importante dar espaço à discussão em sala de aula sobre marcas temporais presentes na letra, fazendo com isso referências a datas e

Revista Leitura V.1 no 55 - jan/jun 2015 - Número temático: Estudos em perspectivas dialógicas. A canção de funk carioca no ensino de Português como Língua Adicional: uma proposta de material didático. José Peixoto Coelho de Souza e Graziela Hoerbe Andrighetti - p. $41-66$. 
fatos que estavam acontecendo neste período. No caso da canção Rap da felicidade, por exemplo, há trechos que se referem a um momento de esperança vivido pelo país com a troca de governo e com a consolidação de uma moeda que talvez trouxesse mais estabilidade econômica à população brasileira. Cabe ao professor sentir se há espaço e interesse em debates maiores e buscas por outras informações.

\section{Conhecendo a canção (Diretoria)}

Nas tarefas propostas sobre a canção Diretoria, os elementos relacionados ao gênero canção, como o estudo da letra e de elementos da música, bem como aspectos da oralidade e questões culturais, seguem sendo abordados. Na primeira tarefa, assim como no estudo do Rap da Felicidade, os alunos são solicitados a ouvir o primeiro minuto da canção e conversar sobre suas impressões. Com base nelas e no título da canção, a próxima pergunta convida os alunos a tentarem prever o conteúdo da letra, a fim de estarem mais preparados para a sua compreensão.

Nas questões 3 e 4, procura-se trabalhar com palavras/expressões mais típicas do estilo de linguagem verbal desse gênero discursivo e refletir sobre o porquê de suas escolhas, uma vez que o uso desses termos acaba por delimitar a interlocução, no sentido de quais ouvintes são capazes de compreendê-los. As palavras selecionadas envolvem posições, sentimentos e comportamentos geralmente presentes no cotidiano dos compositores de funk carioca. Aqui, como na análise da canção anterior, buscamos explorar trechos da letra para debater os temas presentes na canção e os objetivos de quem a escreve, e relacioná-los com a música.

As questões 5 a 11 são direcionadas à compreensão da letra e a reflexões acerca da vida no morro, das posições assumidas e das relações marcadas pelos sujeitos "nós" e "eles". Os alunos são solicitados a comparar esses sujeitos com os sujeitos da canção anterior, refletindo sobre quem são, que posições desempenham e que questões sociais se apresentam. Nesse sentido, o papel da música como meio de expressão das ideias para o MC também é um dos temas importantes tratados na tarefa, a partir da reflexão sobre o que o funk representa para ele, para quem ouve sua música, quem tem interesse em calar essa voz e por quê.

Revista Leitura V.1 no 55 - jan/jun 2015 - Número temático: Estudos em perspectivas dialógicas. A canção de funk carioca no ensino de Português como Língua Adicional: uma proposta de material didático. José Peixoto Coelho de Souza e Graziela Hoerbe Andrighetti - p. $41-66$. 
Acreditamos que chamar a atenção para o reconhecimento de marcas discursivas deixadas pela interlocução (relacionadas à escolha de gírias, expressões, palavras), assim como para a percepção de marcações prosódicas presentes na canção (ênfases dadas em determinadas palavras, sílabas, repetições) coloca os alunos no papel de analistas do texto (LUKE; FREEBODY, 1990 apud GIBBONS, 2002), fazendo-os olhar para os aspectos culturais que permeiam a linguagem, de forma contextualizada.

\section{Refletindo sobre as canções (o funk e os MCs)}

Além das duas canções de funk carioca (Rap da Felicidade e Diretoria) analisadas nas etapas anteriores, nesta tarefa são abordados textos de outros gêneros discursivos, por entendermos que o "trabalho com gêneros do discurso possibilita pensarmos no uso da língua como situado, construído conjuntamente em determinadas condições de produção e, portanto, permeada de valores, avaliações, posicionamentos e escolhas" (ANDRIGHETTI, 2009, p. 86). Na quarta etapa, buscamos ampliar a compreensão das canções ouvidas ao selecionarmos textos biográficos que trazem informações sobre os MCs que as compuseram e interpretaram.

Antes da leitura de um texto sobre o funk carioca e sobre a trajetória dos MCs Cidinho \& Doca, a fim de obter mais informações sobre suas vidas (origem, trajetória, questões identitárias, causas defendidas), os alunos são convidados a ouvir novamente as duas canções e voltar às tarefas de análise a fim de ponderar sobre suas respostas anteriores. Além disso, eles têm a oportunidade de conversar sobre as suas impressões sobre as canções com base no seu gosto pessoal. Entendemos que abordar a fruição dos alunos é uma maneira de estimulálos a exercer seu papel de usuários do texto (LUKE E FREEBODY, 1990 apud GIBBONS, 2002), visto que ouvimos canções também pelo prazer que elas nos proporcionam.

Na questão 3, propõe-se a busca por textos biográficos sobre o MC Sapão na Internet a fim de, a partir da sua leitura, traçar comparativos entre as vidas dos três artistas. Os textos lidos servirão de base para a realização da questão 4, pois, com base no conhecimento construído nas questões anteriores, solicita-que os alunos reanalisem as canções Diretoria e Rap da Felicidade, procurando traçar relações entre as canções e a trajetória de cada MC.

Revista Leitura V.1 no 55 - jan/jun 2015 - Número temático: Estudos em perspectivas dialógicas. A canção de funk carioca no ensino de Português como Língua Adicional: uma proposta de material didático. José Peixoto Coelho de Souza e Graziela Hoerbe Andrighetti - p. $41-66$. 


\section{Ouvindo Música}

Com base em Coelho de Souza (2009), a próxima etapa da unidade didática aqui analisada almeja oferecer aos alunos uma visão mais ampla do funk carioca. Para isso, são propostas a leitura de um artigo sobre o gênero em estudo e a audição de mais quatro canções representativas de diferentes vertentes nele existentes, visto que o funk carioca sofreu transformações com o passar dos anos e adotou bandeiras diferentes com desde o seu surgimento nos anos 1970 (MEDEIROS, 2006; VIANA, 2010). Por essa razão, torna-se fundamental fornecer aos alunos o acesso a mais informações sobre o gênero discursivo em estudo para que possam (re)conhecer como as canções estudadas relacionam-se com as décadas em que foram produzidas. Da mesma forma, procura-se incentivá-los a ir além dos temas tratados na unidade a fim de melhor compreender as razões pelas quais esse gênero musical atrai opiniões acirradas.

Com base nas informações presentes no texto, os alunos têm a oportunidade de ponderar sobre a relação entre os temas tratados nas canções Rap da Felicidade e Diretoria e seus respectivos contextos de produção e sobre a possibilidade de as letras dessas canções serem cantadas em outro gênero musical. Com essa última questão, espera-se que os alunos reflitam sobre a relação existente entre o gênero musical e os temas por ele comumente delimitados (COELHO DE SOUZA, 2010; CARETTA, 2011), e sobre quais sentidos se apagariam e quais sentidos emergiriam a partir da articulação das letras em questão com músicas de outros gêneros musicais.

Esta etapa envolve também a audição comentada de outras canções representativas do funk carioca. Embora o objetivo aqui não seja promover um estudo aprofundado dessas canções, os alunos são convidados a ouvi-las a fim de reconhecer elementos da linguagem musical, como a instrumentação e as sensações provocadas pela audição das canções, e os temas retratados em cada uma delas, a fim de relacioná-las às diferentes fases do funk carioca. Desse modo, espera-se ampliar a visão dos alunos sobre esse gênero através do (re)conhecimento sobre alguns dos elementos mais tipicamente estáveis no funk carioca, tanto os presentes na letra quanto na música, como as temáticas das canções das diferentes vertentes

Revista Leitura V.1 no 55 - jan/jun 2015 - Número temático: Estudos em perspectivas dialógicas. A canção de funk carioca no ensino de Português como Língua Adicional: uma proposta de material didático. José Peixoto Coelho de Souza e Graziela Hoerbe Andrighetti - p. $41-66$. 
e a presença de poucos instrumentos musicais no arranjo, o que acaba por enfocar a batida da música, geralmente levando o ouvinte a dançar.

Para finalizar, após tratarem ao longo da tarefa sobre questões referentes ao papel social do funk carioca, os alunos são convidados a pensar sobre gêneros musicais em seus países que retratem a realidade de grupos similares aos estudados nesta tarefa. Com essa questão, esperamos que os alunos de diferentes nacionalidades (e mesmo os do mesmo país) possam refletir sobre a riqueza dos gêneros musicais existentes no seu país e sobre seus respectivos papéis dentro da sociedade. Esta proposta torna-se importante na medida em que acreditamos que

o ensino de língua e cultura requer também fazer com que os alunos se questionem sobre os valores subjacentes às suas próprias línguas e culturas, fato que vai muito além de simplesmente "comparar" a cultura estudada com as culturas dos alunos, mas passa por fazer esses alunos perceberem regras de comportamento e organização da interação existentes nas suas próprias culturas. (ANDRIGHETTI e SCHOFFEN, 2012 p.20).

\section{O que pensam sobre isso}

A seção $O$ que pensam sobre isso é um convite aos alunos para se inteirar mais sobre o que outras pessoas pensam sobre o funk carioca. Propomos aos alunos que conversem com brasileiros para saber mais sobre suas apreciações, assim como trabalhamos com textos de opinião retirados de fontes diversas, a fim de que os estudantes estrangeiros entrem em contato com diferentes pontos de vista sobre esse gênero musical e tenham mais insumos para construir sua própria opinião sobre o tema. Entendemos que, para isso, possuir os recursos para reconhecer que vozes estão por trás desse gênero e o seu papel na vida das pessoas que o compõem e o ouvem é fundamental para a compreensão dessas respostas.

\section{Produção Escrita}

Por último, a tarefa propõe aos alunos a escrita de um texto de opinião, semelhante aos que foram lidos e discutidos no exercício anterior, posicionando-se com relação ao tema estudado. Para dar conta dessa produção, os alunos terão que lançar mão das conversas e discussões realizadas em aula, das suas leituras e também das suas impressões ao se

Revista Leitura V.1 no 55 - jan/jun 2015 - Número temático: Estudos em perspectivas dialógicas. A canção de funk carioca no ensino de Português como Língua Adicional: uma proposta de material didático. José Peixoto Coelho de Souza e Graziela Hoerbe Andrighetti - p. $41-66$. 
depararem com as canções ouvidas, reagindo criticamente aos diferentes textos estudados. Nesta etapa, pode se tornar relevante discutir com os alunos o uso de diferentes estruturas de opinião e argumentação e também propor reflexões acerca da escolha de recursos linguísticos e vocabulários apropriados para o gênero em questão.

\section{Considerações finais}

Afiliando-nos a perspectiva da educação linguística (BRASIL, 1998; SCHLATTER, 2009; RIO GRANDE DO SUL, 2009; SCHLATTER; GARCEZ, 2012) que afirma que a leitura e escrita de textos de diferentes gêneros do discurso permitem ampliar as competências comunicativas e promovem o(s) letramento(s) dos educandos, apresentamos e analisamos neste trabalho uma unidade didática cujo gênero estruturante é a canção de funk carioca, com o intuito de refletir sobre o papel desses materiais no estímulo a práticas pedagógicas que propiciem a leitura como prática social.

Partindo do pressuposto que a canção é um gênero sincrético formado por letra e música (CARETTA, 2007, 2011; COELHO DE SOUZA, 2010) e que o gênero musical ao qual uma canção pertence determina não apenas os elementos constitutivos da música, mas também da letra, e projeta possíveis contextos de produção, circulação e recepção (COELHO DE SOUZA, 2010), acreditamos que os materiais didáticos com base em canções devem convidar os alunos a refletir sobre os diferentes aspectos envolvidos na construção de sentidos da canção em estudo. Isso envolve, por exemplo, ter em vista suas duas linguagens constitutivas e sua articulação entre si, e que, tal como qualquer gênero do discurso, a mesma está imbricada a todo um contexto de produção e interlocução permeado por questões culturais e axiológicas. Ademais, por entender a canção de funk carioca como gênero discursivo, pensamos que se torna relevante abordar questões referentes ao contexto de produção onde ela ocorre (quem a produz, com que objetivos, que papel esse gênero musical desempenha na sociedade, quem ganha voz através dele, etc.), fornecendo assim insumos para que os alunos possam posicionar-se mais criticamente em relação ao texto e ao gênero em estudo (BRASIL, 1998; SCHLATTER, 2009; RIO GRANDE DO SUL, 2009; SCHLATTER; GARCEZ, 2012).

Revista Leitura V.1 no 55 - jan/jun 2015 - Número temático: Estudos em perspectivas dialógicas. A canção de funk carioca no ensino de Português como Língua Adicional: uma proposta de material didático. José Peixoto Coelho de Souza e Graziela Hoerbe Andrighetti - p. $41-66$. 
$\mathrm{Na}$ perspectiva aqui defendida, o aluno, na posição de leitor crítico, torna-se decodificador, participante, usuário e analista do texto ao reconhecer as características presentes nas letras e músicas das canções de funk carioca, a fim de compreender os propósitos dessas canções, entender as questões político-sociais que as motivam, visualizar possíveis interlocutores, reconhecer empoderamentos, perceber preconceitos e discriminações, e ver caminhos que se abrem através dessas canções. Saber reconhecer a canção de funk carioca como gênero discursivo é entender sua circulação social, o que está por trás das escolhas feitas na letra e nos arranjos musicais, é saber opinar em relação a isso, é decidir se esta canção fará parte das canções que se quer ouvir no dia a dia e em que circunstâncias. Nesse sentido, entendemos que tarefas como as presentes na unidade didática analisada neste artigo podem estimular os alunos a tornarem-se leitores/ouvintes mais ativos e críticos frente ao que leem, visto que,

\begin{abstract}
Através da vivência continuada e aprofundada com textos relevantes, desafiadores e instigantes [...], busca-se promover a compreensão e a reflexão sobre o seu lugar e sua posição como cidadãos - incluídos e excluídos de determinados contextos - e inserir-se criticamente em novos campos de atuação humana. (SCHLATTER, 2009, p. 20).
\end{abstract}

\title{
Referências
}

ANDRIGHETTI, G. H. A elaboração de tarefas de compreensão oral para o ensino de português como língua adicional em níveis iniciais. Dissertação de Mestrado. PPG-UFRGS, 2009.

ANDRIGHETTI, G. H.; SCHOFFEN, J. R. Vivenciando Língua e Cultura: sugestões para práticas pedagógicas em Português como Língua Adicional. In: Juliana Roquele Schoffen; Simone Paula Kunrath; Graziela Hoerbe Andrighetti; Letícia Grubert dos Santos. (Org.). Português como Língua Adicional: Reflexões para a Prática Docente. 1 ed. Porto Alegre, 2012, v. 1, p. 17-44.

BAKHTIN, M. Estética da criação verbal. São Paulo: Martins Fontes, 2003.

BRASIL. Secretaria de Educação Fundamental. Parâmetros Curriculares Nacionais: terceiro e quarto ciclos do ensino fundamental: língua estrangeira. Brasília: MEC/SEF, 1998.

Neste trabalho, entendemos unidade didática como uma sequência de tarefas pedagógicas

Revista Leitura V.1 no 55 - jan/jun 2015 - Número temático: Estudos em perspectivas dialógicas. A canção de funk carioca no ensino de Português como Língua Adicional: uma proposta de material didático. José Peixoto Coelho de Souza e Graziela Hoerbe Andrighetti - p. $41-66$. 
CARETTA, A. A. Relações discursivas entre a canção popular e os gêneros primários da comunicação. Estudos Linguísticos. São Paulo. v. 36, n. 3, set/dez de 2007, p. 158-165.

A canção e a cidade: estudo dialógico discursivo da canção brasileira e seu papel na constituição do imaginário da cidade de São Paulo na primeira metade do século XX. Tese (Doutorado em Semiótica e Linguística Geral) - Departamento de Linguística, Universidade de São Paulo, São Paulo, 2011.

COELHO DE SOUZA, J. P. A canção nos livros didáticos de Português como Língua Adicional. Em preparação.

.A canção na ótica dos gêneros discursivos: uma constelação de gêneros. Cadernos do IL. Porto Alegre, n. ${ }^{\circ}$ 40, junho de 2010. p. 123-133.

Canção Brasileira: proposta de material didático para um curso de Português como Língua Adicional. 2009. Monografia (Graduação em Letras), Porto Alegre: Universidade Federal do Rio Grande do Sul, 2009.

COSTA, N. B. da. As letras e a letra: o gênero canção na mídia literária. In: Ângela Paiva Dionísio; Anna Rachel Machado; Maria Auxiliadora Bezerra. (Org.). Gêneros textuais e ensino. Rio de Janeiro: Lucerna, 2002, p. 107-121.

GIBBONS, P. Scaffolding language, scaffolding learning: Teaching second language learners in the midstream classroom. Portsmouth, NH: Heinemann, 2002.

MEDEIROS, J. Funk carioca: crime ou cultura? O som dá medo. E prazer. São Paulo: Editora Terceiro Nome, 2006.

OLIVEIRA, L. X. de. O swing do samba: uma compreensão do gênero do samba-rock a partir da obra de Jorge Ben Jor. Dissertação de Mestrado - Faculdade de Comunicação, Universidade Federal da Bahia, Salvador, 2008.

RIO GRANDE DO SUL. Línguas adicionais (espanhol e inglês). Referenciais Curriculares do Estado do Rio Grande do Sul: Linguagens, Códigos e suas Tecnologias. Porto Alegre: SE/DP, v. 1, p. 127-172, 2009.

RODRIGUES, R. H. Os gêneros do discurso na perspectiva dialógica da linguagem: a abordagem de Bakhtin. In: MEURER, J. L., BONINI, A., MOTTA-ROTH, D.(Orgs). Gêneros: teorias, métodos, debates. São Paulo: Parábola Editorial, 2007.

SCHLATTER, M.. O ensino de língua estrangeira na escola: uma proposta de letramento. Calidoscópio, vol.7, n. 1, p. 11-23, jan/fev 2009.

.; GARCEZ, P. M. Línguas Adicionais na escola: aprendizagens colaborativas em inglês. Erechim: Edelbra, 2012.

Revista Leitura V.1 no 55 - jan/jun 2015 - Número temático: Estudos em perspectivas dialógicas. A canção de funk carioca no ensino de Português como Língua Adicional: uma proposta de material didático. José Peixoto Coelho de Souza e Graziela Hoerbe Andrighetti - p. $41-66$. 
SOARES, M.B. Letramento: um tema em três gêneros. Belo Horizonte: Autêntica, 1999.

VIANA, L. R. O Funk no Brasil: música desintermediada na cibercultura. Sonora, v. 3-5, 2010, p. 3-23.

\section{Anexo}

I - Pra Começar

1. Converse com o seu colega sobre as perguntas abaixo sobre três comentários postados em uma página da internet.

a) Você já ouviu falar em funk carioca? O que as opiniões a seguir revelam sobre esse gênero musical?

b) As pessoas abaixo gostam ou não gostam de funk carioca? Como você sabe?

c) Você concorda ou discorda das opiniões lidas? Por quê?

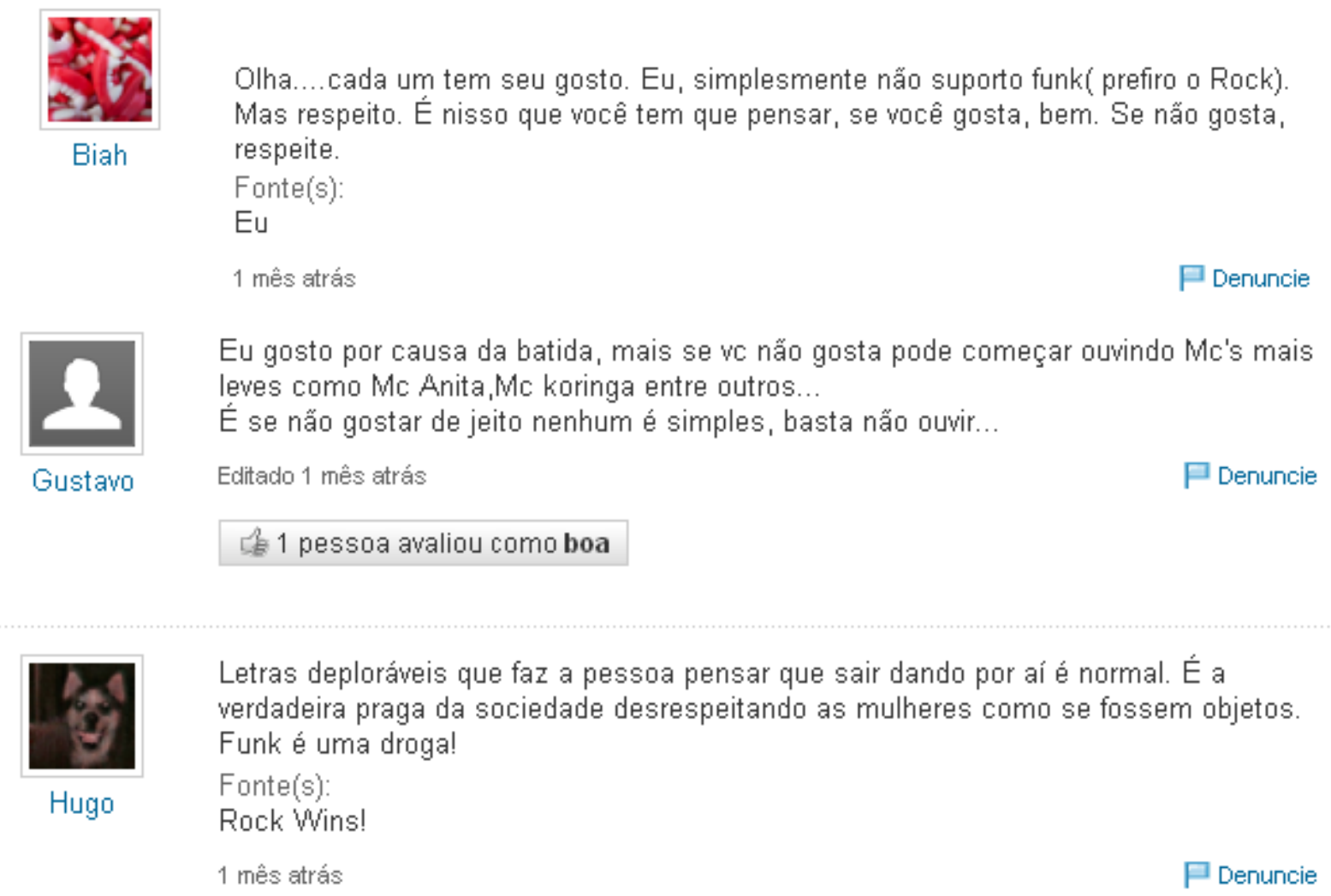

Fonte: $\underline{\text { http://br.answers.yahoo.com/question/index?qid=20130418170039AAY0Q8g }}$

2. Converse com o seu colega sobre as seguintes perguntas:

a) O que você conhece sobre o Rio de Janeiro?

Revista Leitura V.1 no 55 - jan/jun 2015 - Número temático: Estudos em perspectivas dialógicas. A canção de funk carioca no ensino de Português como Língua Adicional: uma proposta de material didático. José Peixoto Coelho de Souza e Graziela Hoerbe Andrighetti - p. $41-66$. 
b) Que gêneros musicais você associa a essa cidade?

c) O funk carioca é um gênero musical muito popular no Rio de Janeiro e também no Brasil. O que você sabe sobre o funk (como e onde surgiu, que objetivos tinha/tem, quem eram/são seus ouvintes, que temas são tratados nas suas canções)?

II - Conhecendo a Canção - Rap da Felicidade

1. Você vai ouvir o refrão da canção "Rap da Felicidade" de Cidinho \& Doca, composta em 1994. Ouça e complete a tabela abaixo, justificando suas impressões. Depois compare suas respostas às respostas dos colegas.

\begin{tabular}{|c|c|c|c|c|}
\hline Instrumentos & Andamento & Vocal & Sensação & Propósito \\
(1 / 2 ou 3 / 4 ou +) & (rápido / médio / lento) & $\begin{array}{c}\text { (cantado / falado / gritado } \\
\text { /...) }\end{array}$ & $\begin{array}{c}\text { (felicidade / tristeza / saudade / } \\
\text {...) }\end{array}$ & (dançar / relaxar / ...) \\
\hline & & & & \\
\hline
\end{tabular}

2. Ouça novamente o refrão da canção. Converse com seu professor e colegas sobre as questões a seguir:

a. Qual é a função do refrão em uma canção?

b. O que diz o refrão desta canção?

c. O cantor repete uma mesma palavra algumas vezes. Que palavra é essa? Que sensação isso provoca em você?

d. Que função o trecho "Fé em Deus, DJ" têm neste refrão? Como ele se relaciona com a música?

3. As palavras listadas a seguir foram retiradas da letra da canção. Após analisá-las, que imagens elas trazem a você? Com base no título, no refrão e nas palavras abaixo, sobre o que você acha que a canção trata? Compare suas respostas com as respostas dos colegas.

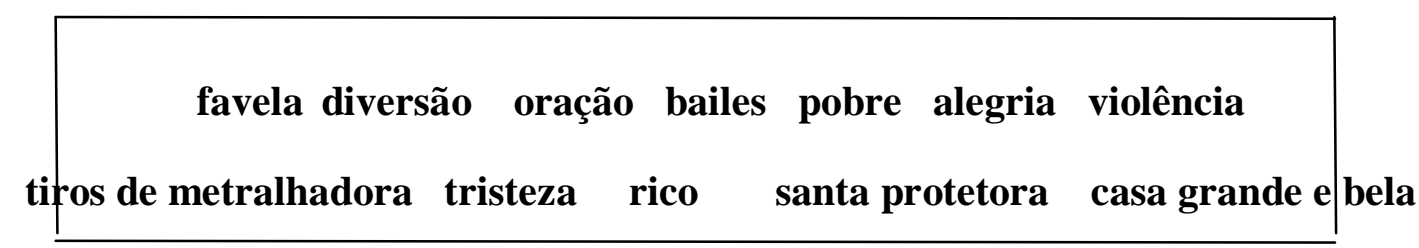

4. Agora ouça a canção e complete as lacunas com as palavras listadas no exercício anterior. Após fazer isso, analise novamente as estrofes. Suas impressões se confirmaram? Sobre o que trata a canção?

Revista Leitura V.1 no 55 - jan/jun 2015 - Número temático: Estudos em perspectivas dialógicas. A canção de funk carioca no ensino de Português como Língua Adicional: uma proposta de material didático. José Peixoto Coelho de Souza e Graziela Hoerbe Andrighetti - p. $41-66$. 


\section{REFRÃO}

Eu só quero é ser feliz

Andar tranquilamente na favela onde eu nasci, é

$E$ poder me orgulhar

E ter a consciência que o pobre tem seu lugar

Fé em Deus, DJ

\section{REFRÃO}

Mas eu só quero é ser feliz, feliz, feliz, feliz, feliz, onde eu nasci

$E$ poder me orgulhar e ter a consciência que o pobre tem seu lugar

(Estrofe 1)

Minha cara autoridade, eu já não sei o que fazer

Com tanta eu sinto medo

de viver

Pois moro na

desrespeitado

A

lado a lado

e

Eu faço uma para uma

Mas sou interrompido a

(Estrofe 2)

Enquanto os moram numa

$\bar{O}$ é humilhado, esculachado na favela

Já não aguento mais essa onda de violência

Só peço à autoridade um pouco mais de competência

REFRÃO

Mas eu só quero é ser feliz, feliz, feliz, feliz, feliz, onde eu nasci, é

Revista Leitura V.1 no 55 - jan/jun 2015 - Número temático: Estudos em perspectivas dialógicas. A canção de funk carioca no ensino de Português como Língua Adicional: uma proposta de material didático. José Peixoto Coelho de Souza e Graziela Hoerbe Andrighetti - p. $41-66$.

E poder me orgulhar e ter a consciência que o pobre tem seu lugar

\section{(Estrofe 3)}

nem pensar

Pois até lá nos , eles vem nos humilhar

Ficar lá na praça que era tudo tão normal

Agora virou moda a violência no local Pessoas inocentes, que não tem nada a ver

Estão perdendo hoje o seu direito de viver

\section{(Estrofe 4)}

Nunca vi cartão postal que se destaque uma favela

Só vejo paisagem muito linda e muito bela

Quem vai pro exterior da favela sente saudade

O gringo vem aqui e não conhece a realidade

Vai pra zona sul, pra conhecer água de coco

E o pobre na favela, vive passando sufoco

\section{(Estrofe 5)}

Trocaram a presidência, uma nova esperança

Sofri na tempestade, agora eu quero a bonança

$O$ povo tem a força, precisa descobrir Se eles lá não fazem nada, faremos tudo daqui 
5. Observe a estrofe 3. Segundo a letra, como era o cotidiano na favela? O que mudou?

6. Analise a estrofe 4:

Nunca vi cartão postal que se destaque uma favela

Só vejo paisagem muito linda e muito bela

Quem vai pro exterior da favela sente saudade

$O$ gringo vem aqui e não conhece a realidade

Vai pra zona sul, pra conhecer água de côco

E o pobre na favela, vive passando sufoco

a) Que paralelos o autor traça entre a favela e o "exterior da favela"?

b) Você compreende o que o autor quer dizer com "gringo" e "zona sul"?

7. Observe as frases a seguir retiradas da letra da canção.

“(nós) não podemos nem pensar" (linha 1 da estrofe 3 )

“(nós) faremos tudo aqui”" (linha 4 da estrofe 5)

"Eles vem nos humilhar" (linha 3 da estrofe 3 )

"se eles lá não fazem nada" (linha 4 da estrofe 5)

a) A quem o compositor se refere quando diz "nós"? Justifique sua resposta.

b) A quem o compositor se refere ao usar "Eles" na linha 3 da estrofe 3? E ao usar "eles" na linha 4 da estrofe 5? Como você sabe?

8. De que modo os compositores retratam a vida na favela? Quais são os seus sentimentos com relação a ela? Como você sabe?

9. Na sua opinião, o ponto de vista do compositor sobre a vida no morro é otimista, pessimista ou realista? Por quê?

10. A quem o compositor está se dirigindo ao escrever a canção? Com que propósito?

11. Você acha que a letra combina com a música? Por quê?

III - Conhecendo a Canção - Diretoria

1. Você vai ouvir um trecho da canção "Diretoria" de MC Sapão, lançada em 2003. Ouça e complete a tabela abaixo e depois compare com a do seu colega. Lembre-se de justificar suas impressões.

\begin{tabular}{|c|c|c|c|c|}
\hline Instrumentos & Andamento & Vocal & Sensação & Propósito \\
$(1 / 2$ ou $3 / 4$ ou +$)$ & (rápido / médio / lento) & $\begin{array}{c}\text { (cantado / falado / gritado } \\
\text { /...) }\end{array}$ & $\begin{array}{c}\text { (felicidade / tristeza / saudade / } \\
\text {...) }\end{array}$ & (dançar / relaxar / ...) \\
\hline
\end{tabular}




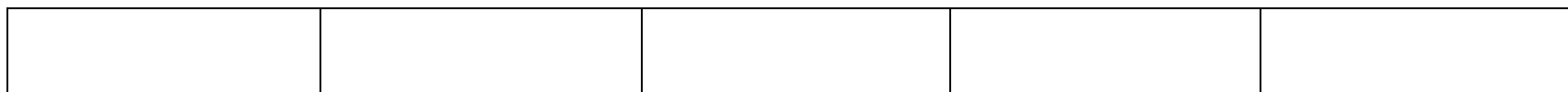

2. Com base no trecho que você escutou e no título da canção, sobre o que acha que ela trata? Compare a sua opinião com a do seu colega.

3. Agora ouça a canção até o fim e acompanhe a letra. As suas expectativas se confirmaram?

\section{Diretoria}

Letra e Música: MC Sapão

\section{REFRÃO}

O natural do Rio é o batidão

a playboyzada e os manos do morrão

funkeiro é nós com muita disciplina

www.com Brasília

quero ouvir, vamo lá...

Diretoria tá de pé, é nós, mané, esse é o funk do Rio de Janeiro

o lema é paz, justiça, liberdade

$100 \%$ humildade, sem neurose e sem caô, é

Vida de MC que eu tô vivendo, vou levando no talento para a vida melhorar

o clima aqui está díficil

se liga meu amigo não vou parar de cantar

eu peço a Deus para que olhe por nós

prlom bom bom bom bom (2X)

Já perdi vários amigos mas não calarão a minha voz

fala que é nós, é

sou guerreiro, sou certo e não admito falha

Favela é só papo reto, não somos fãs de canalha

sou guerreiro, sou certo e não admito falha

Favela é só papo reto, não somos fãs de canalha

\section{REFRÃO (2X)}

4. É muito comum nas letras de funk os compositores utilizarem gírias típicas dos moradores das favelas cariocas. Você compreende as partes em destaque na letra? Relacione-as com seus significados nas colunas a seguir.
a) Batidão
( ) mentira
b) Mané
( ) verdade
c) Caô
( ) Mestre de Cerimônia, funkeiro
d) $\mathrm{MC}$
( ) amigos, parceiros 
e) Papo reto ( ) homens de posses que, não tendo ocupação certa, passam o tempo em diversões ${ }^{9}$
f) Manos
( ) cara
g) Playboyzada
( ) funk

5. Que função o trecho "Quero ouvir, vamo lá..." tem na canção? Como ele se relaciona com a música?

6. Como você entende o refrão da canção? O que ele nos diz sobre a relação entre o funk carioca e a cidade do Rio de Janeiro? E sobre os manos e a playboyzada?

7. Com base no trecho a seguir:

a) o que podemos inferir sobre o funk carioca? Aponte no texto justificativas para suas respostas.

b) o que podemos inferir sobre a vida de MC? Aponte no texto justificativas para suas respostas.

Vida de MC que eu tô vivendo, vou levando no talento para a vida melhorar o clima aqui está díficil se liga meu amigo não vou parar de cantar eu peço a Deus para que olhe por nós prlom bom bom bom bom (2X)

Já perdi vários amigos mas não calarão a minha voz fala que é nós, é sou guerreiro, sou certo e não admito falha Favela é só papo reto, não somos fãs de canalha sou guerreiro, sou certo e não admito falha Favela é só papo reto, não somos fãs de canalha

8. Observe as frases a seguir retiradas da letra da canção. Os "nós" $e$ "eles" retratados nesta canção são os mesmos da canção anterior? Justifique sua resposta.

"Funkeiro é nós com muita disciplina"

"Diretoria tá de pé, é nós, mané, esse é o funk do Rio de Janeiro"

"Eu peço a Deus para que olhe por nós"

"Já perdi vários amigos mas (eles) não calarão a minha voz"

"Favela é só papo reto, (nós) não somos fâs de canalha"

9. De que modo o compositor retrata a sua vida no morro?

10. Você acha que a letra combina com a música? Por quê?

9 Fonte: http://www.dicio.com.br/playboy/ 
11. Com base na letra da canção e no que foi discutido em aula, o que o funk carioca representa para o MC? E para a favela?

IV - Refletindo sobre as Canções - o Funk Carioca e os MCs

1. Retome as suas respostas às questões dadas nos quadros na seção II e III e ouça novamente os funks "Diretoria" e "Rap da felicidade". Suas respostas ainda seriam as mesmas? Você gostou das canções? Por quê?

2. Você já tinha ouvido falar de MC Sapão e MC Cidinho \& Doca? O texto a seguir traz algumas informações sobre Cidinho \& Doca. Após lê-lo, converse com o seu colega sobre a sua trajetória e suas identidades.

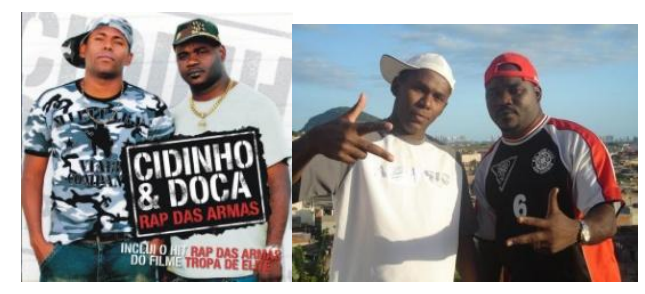

Nascido em um cruzamento entre o Miami Bass americano - uma variação primitiva do hip hop - e a linguagem característica dos morros e favelas do Rio de Janeiro, o funk carioca não encontra barreiras sociais em sua implacável expansão. Do sujeito mais rico ao mais humilde, todos curtem funk carioca. Uma batida seca, letras maliciosas, geralmente falando de sexo ou exaltando a malandragem - e às vezes até a bandidagem são defendidas por duplas de MCs como os populares Cidinho e Doca, da Cidade de Deus.

Cidinho e Doca é um dueto de rap formado por Sidney da Silva (MC Cidinho) e Marcos Paulo de Jesus Peixoto (MC Doca). Com origem na favela Cidade de Deus, em Jacarepaguá, no Rio de Janeiro e influências do proibidão. Uma de suas músicas mais famosas é a canção "Rap das Armas" de 1994. Na época já famosa, a música era vetada nas rádios porque cita inúmeras armas de grosso calibre e de guerra, sendo cantada como referência por traficantes do Comando Vermelho, que dominava a região da Cidade de Deus até a instalação da UPP. Ao mesmo tempo, Cidinho e Doca faziam sucesso com canções pedindo paz, amor, humildade, numa época em que os bailes funk eram famosos pelas brigas generalizadas entre os chamados "Lado A" e "Lado B". Com o lançamento do filme Tropa de Elite a música fez sucesso novamente, sendo a trilha sonora principal do filme. Também foi lançada nos Estados Unidos e Portugal. Outros singles da dupla são "Rap da Cidade de Deus", "É o Bonde da CDD", "Rap da Felicidade".

Fonte: texto adaptado de http://www.lastfm.com.br/music/Cidinho+\&+Doca e http://pt.wikipedia.org/wiki/Cidinho_e_Doca)

Glossário 
Miami Bass - tipo de hip hop popular nos EUA nos anos 1980 e 1990 que utiliza uma batida de dança continuada e dançante e que às vezes possui letras com forte conteúdo sexual.

Proibidão - subgênero do funk carioca que exalta a violência e o tráfico de drogas.

3. Busque na internet informações sobre o MC Sapão. Que comparações podem ser feitas com a trajetória de Cidinho \& Doca?

4. A leitura destes textos propiciou novas interpretações sobre as canções analisadas anteriormente? Por quê?

V - Ouvindo Música

1. O texto abaixo apresenta um panorama do gênero funk carioca durante os anos 1990 e 2000 . Leia o texto e converse com seu colega sobre as seguintes perguntas:

a) As canções "Rap da felicidade" e "Diretoria" remetem aos anos 90 e início de 2000. Que relações você faz entre as canções e seus contextos de criação?

b) Com base nos textos que você leu nesta tarefa e na anterior, você acha que as letras das canções estudadas poderiam ser cantadas em algum outro gênero musical? Por quê?

Nos anos 90, as letras do funk carioca falavam das dificuldades que os moradores de favelas do Rio de Janeiro passavam como a discriminação racial e social vista em todos os lugares, praças, shopping, praias, cinemas, teatro, estádio de futebol (Maracanã), e outros. O funk carioca apresentava um discurso contra as brigas nos bailes funk, o chamado "corredor", formados por pessoas que se denominavam fazer parte do lado A e do lado B, e que assim se organizavam e brigavam.

As letras falavam ainda das revistas policiais que os jovens moradores de favelas passavam em público, e que nessa época era visto como arma político-ideológica, além de temas relacionados ao amor (funk melody).

Em meio a isso, surgiu uma nova vertente do funk carioca, o funk melody, com músicas mais melódicas e temas mais românticos, seguindo mais fielmente a linha musical do freestyle americano e alcançando sucesso nacional. Destacaram-se, nesta primeira fase, Latino, Copacabana Beat, MC Marcinho, entre outros.

Nos anos 2000, o funk passou por algumas mudanças. As músicas mais famosas produzidas neste período tomaram uma direção diferente das criadas na década anterior, com uma conotação mais sexual, letras ora de duplo sentido, relatando posições sexuais, ora dizendo explicitamente palavras de baixo calão. Nestas canções as dificuldades da população da favela são postas um pouco à parte e toma vigor a visão do baile funk como reunião social para paquera, namoro e flerte. $O$ envolvimento com o tráfico é ignorado.

Nessa década passou a haver uma participação maior das mulheres no funk carioca. Alguns grupos como As Danadinhas, Gaiola das Popozudas ou MCs como Tati QuebraBarraco, MC Sabrina e Perlla chegam às paradas de sucesso. As músicas destas 
costumam falar sobre o lado sensual dos bailes funk pela visão feminina, a liberação sexual das mulheres e relacionamentos amorosos de um modo geral. Temas como "quem paga o motel sou eu", "vou chifrar o seu marido", "amantes vs. fiéis", são comuns.

Fonte: texto adaptado de http://pt.wikipedia.org/wiki/Funk_carioca

2. Você vai escutar quatro canções que representam o gênero musical funk carioca em diferentes épocas. Acompanhe as letras e preste atenção na música para preencher a tabela abaixo com as suas impressões.

\begin{tabular}{|l|l|l|l|l|}
\hline \multicolumn{1}{|c|}{ Canção } & $\begin{array}{c}\text { Instrumentos } \\
(1 / 2 \text { ou } 3 / 4 \text { ou }+)\end{array}$ & $\begin{array}{c}\text { Andamento } \\
\text { (rápido / médio / } \\
\text { lento) }\end{array}$ & $\begin{array}{c}\text { Sensação } \\
\text { (felicidade/ saudade /...) }\end{array}$ & $\begin{array}{c}\text { Algo que } \\
\text { chamou a sua } \\
\text { atenção }\end{array}$ \\
\hline $\begin{array}{l}\text { 1. Rap das Armas } \\
(\text { 1994) }\end{array}$ & & & & \\
\hline $\begin{array}{l}\text { 2. Bonde do Tigrão } \\
\text { (2001) }\end{array}$ & & & & \\
\hline $\begin{array}{l}\text { 3. Boladona (2004) } \\
\text { 4. Ela só pensa em } \\
\text { beijar (2006) }\end{array}$ & & & & \\
\hline
\end{tabular}

3. Você acha que há algum elemento em comum entre as canções que você acabou de ouvir? Caso afirmativo, qual(is)?

4. E no seu país? Existem gêneros musicais que retratam a realidade de grupos similares aos estudados nesta tarefa? Quais? De que forma eles fazem isso (ritmo, letra, dança, temas abordados, etc.)?

VI - O Que Pensam Sobre Isso?

1. Entreviste 3 brasileiros perguntando a opinião deles sobre o funk carioca:

a) Você costuma ouvir funk carioca? Em que ocasiões?

b) Você gosta de funk carioca? Por quê?

2. Leia as seguintes opiniões retiradas de três páginas da internet sobre o funk carioca e converse com o seu colega sobre as seguintes perguntas:

a) As pessoas abaixo gostam ou não gostam de funk carioca? Como você sabe?

b) Você concorda ou discorda das opiniões lidas? Por quê? 


\section{jefferson2010116 meses atrás}

\section{qual sua opinião sobre o funk carioca?}

respeito quem gosta, mais a letras das musicas para mim nẫo faz sentido mais

\section{SUZETECG 16 meses atrás}

Para mim é um ataque ao bom senso e pudor. O funk inicial de Claudinho e Buchecha era romantico tinha letra....os de hoje em dia só falam de pente, pente, pente...virou ate pornografia em muitos casos...mas nada contra quem goste.

Fonte: http://br.toluna.com/opinions/1075354/qual-opiniao-sobre-funk-carioca.htm

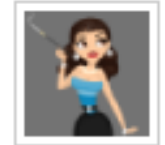

Dai

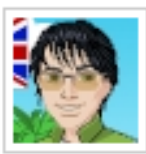

Slider

A.tual, antigo...tudo porcaria que nẫo acrecenta em nada o cenário musical brasileiro, sem falar na linguagem vulgar e depreciativa. $x]$

4 anos atrás

Um lixo nẫo tem mais a mesma irreverencia de tempos antigos como furacẫo $2000 \mathrm{e}$ tati quebra barraco

4 anos atrás

1 pessoa avaliou como boa

Fonte: $\underline{\text { http://br.answers.yahoo.com/question/index?qid=20090128102222AAhKyCv }}$

Por Thiago Borges, jornalista e co-responsável pelo site Periferia em Movimento

“É SOM DE PRETO, DE FAVELADO, MAS QUANDO TOCA NINGUÉM FICA PARADO".

E, convenhamos, há muitos anos ninguém fica parado quando toca funk carioca - seja nas lajes, nos carros, no meio da rua... Moro na periferia de São Paulo, capital do rap nacional, não do funk carioca. Confesso que, até alguns anos atrás, alimentei um preconceito burro (como todo preconceito) contra o ritmo que soava das favelas do Rio pras quebradas paulistanas.

Então, passei a entender que, pra quem faz o funk, o ritmo tem importante significado.

$O$ funk revela muito do nosso momento atual. A letra pode ser considerada pobre por muitos porque fica em cima de sexo e humor, geralmente. Assim como qualquer outro indivíduo, a molecada do morro também quer se expressar e falar do seu dia a dia, que inclui vida sexual ativa (adolescentes transam!). E, sem saber o que é metáfora, manda o papo reto, sem enrolação. $O$ funk virou meio de comunicação!

Fonte: http://periferiaemmovimento.wordpress.com/2012/08/29/opiniao-o-dia-em-que-me-torneium-admirador-do-funk-carioca/

VII - Produção Escrita

1. Deixe também a sua opinião. Com base nas discussões realizadas ao longo desta unidade, escreva um texto posicionando-se a respeito do funk carioca para ser publicado 
numa das três páginas da internet mencionadas nos comentários lidos por você na etapa anterior. 